\title{
IMMUNOPATHOGENIC TREATMENT OPTIONS FOR PSORIASIS PATIENTS UNDER A RESTRICTIVE REIMBURSEMENT ENVIRONMENT
}

\author{
Ilona Hartmane ${ }^{1,2, \#}$, Iveta Ivdra ${ }^{1,2}$, Ingmārs Mikažāns ${ }^{1,2}$, \\ and Vanda Bondare-Ansberga ${ }^{1}$ \\ ${ }^{1}$ Clinical Centre of Skin and Sexually Transmitted Diseases, Rīga 1st Hospital, 2 Aristīda Briāna Str., Rīga, LV-1001, LATVIA \\ 2 Department of Dermatology, Rīga Stradinš̌ University, 16 Dzirciema Str., Rīga, LV-1007, LATVIA \\ \# Corresponding author, ilona.hartmane@rsu.Iv
}

Communicated by Ludmila Vīksna

This article is aimed to provide an overview of psoriasis clinical aspects, available treatment options for moderate-to-severe psoriasis in Baltics and summarises recommendations of authors for use of different biologicals in psoriasis patients under a limited reimbursement environment.

Keywords: autoimmune skin disorder, biological therapy, state compensation, Baltic.

\section{INTRODUCTION}

One of the most common autoimmune dermatoses with a chronic relapsing course is psoriasis. Its prevalence in Europe ranges from 2\% to 5\% (Christopher et al., 2001; Parisi et al., 2013).

Latvia, together with other Baltic countries, is lowprevalence psoriasis country, varying from $0.13 \%$ to $1.75 \%$ of the total population. There are around 40000 psoriasis patients in Latvia, and similar prevalence rates are observed in Estonia and Lithuania, corresponding to about 35000 and 76000 psoriasis patients, respectively (Hartmane et al., 2016; Global Psoriasis Atlas...). According to literature, the prevalence of moderate psoriasis, defined by body surface area $(\mathrm{BSA})>2-10 \%$, varies from $15 \%$ to $35.8 \%$, and severe psoriasis, defined by BSA > 10\%, from $5 \%$ to $12.4 \%$ (Menter et al., 2011; Yeung et al., 2013).

Therapy of patients with moderate-to-severe psoriasis holds on tree pillars - systemic therapies of non-biological origin (e.g., methotrexate, cyclosporin, apremilast), phototherapy and biological therapy (anti-TNF $\alpha$, Il-12/23 inhibitors, Il-17 inhibitors and Il-23 inhibitors). The location of the disease and the presence of psoriatic arthritis also affect the choice of therapy. Psoriasis of the hand, foot, or face can be debilitating functionally or socially and may deserve a more aggressive treatment approach. Topical treatments, even though they are cheap, accessible and can be used as adjunct treatment for localised lesions, cannot provide satisfying disease control and fail to meet treatment targets as monotherapy for moderate-to-severe psoriasis. Attempts to successfully treat patients with extensive disease require availability and accessibility of appropriate treatment modalities, that would not be limited by prescription lines and would allow to select treatment based on clinical need. Each of the Baltic countries has a distinct approach to therapy reimbursement and different accessibility of treatment, usually limiting the possibility to tailor treatment according to patient needs. This article aims to provide an overview of psoriasis phenotypes, immunopathogenics and treatment in a restrictive reimbursement environment.

\section{OVERVIEW OF PSORIASIS CLINICAL ASPECTS}

Psoriasis can develop at any age and affect not only the skin, but also other organs and organ systems. Psoriasis is a multifactorial disease determined by genetic and environmental factors, disorders of keratinocyte proliferation and differentiation, congenital and adaptive immunity disorders, as well as a multitude of alterations in the body's homeostasis. Morphologically it manifests as epidermal cell proliferation, disorders of keratinisation and inflammatory skin reaction. Clinically it manifests as squamous erythematous papules and lesions. The most common complications are 
psoriatic arthritis (PsA) and erythroderma (Hartmane et al., 2016; Rendon et al., 2019).

Psoriasis has a significant impact on the patients' quality of life. The physical and moral distress it causes is similar to that in cases of other serious conditions, like oncological, cardiovascular disease, diabetes, arthritis, and depression (Möller et al., 2015). There is a high incidence of organ and systemic co-morbidities in patients with psoriasis, particularly in severe cases: arterial hypertension, hyperlipidaemia, major adverse cardiovascular events, obesity, diabetes, and IBD, which often limits the use of CST in the treatment (Takeshita et al., 2017). Biological therapy should be considered for use in patients with moderate to severe psoriasis when conventional systemic therapies and phototherapy are ineffective or their use is limited due to the patient's poor quality of life (Dubertret et al., 2006; Mrowietz et al., 2011; Hartmane et al., 2016). A characteristic feature of psoriasis vulgaris is an erythematous papule with distinct borders and silvery scales. These lesions are most seen on the scalp and extensor surface of elbows and knees. As the papular elements increase in size and converge, infiltrative foci are formed, covered with thick scaly crusts (Griffiths et al., 2007).

The most common phenotypes or clinical subtypes of psoriasis are psoriasis guttata; psoriasis intertriginosa (or inverse psoriasis), psoriasis palmoplantare, and erythrodermia psoriatica (Rahman et al., 2005; Griffiths et al., 2007; Hartmane et al., 2016; Rendon et al., 2019).

Arthritis psoriatica (psoriatic arthritis) is a chronic joint inflammation in psoriasis. More often, this form develops several years after the first manifestations of psoriatic rash, but in some patients, it is diagnosed before psoriasis. According to the literature, psoriatic arthritis affects $0.35-1 \%$ of the general population and $5-30 \%$ of the total number of patients with psoriasis. The highest incidence occurs between 45 and 54 years of age, about ten years after the first skin rash develops (Eder et al., 2016).
Today the leading role of immune-mediated chronic inflammation in the development of psoriasis and psoriatic arthritis has been convincingly demonstrated. These processes are mediated by the interaction of keratinocytes with cells of the innate (myeloid and plasmocytic cells, dendritic cells, macrophages, natural killers) and adaptive immune systems (T lymphocytes). The course and outcome of the disease depend on the severity of immunological disorder and the intercellular effects of cytokine regulation (Reich et al., 2012; Owczarczyk-Saczonek et al., 2018; Christophers et al., 2019). Immunological disorders in psoriasis are due to activation of the cellular immune response with the leading role belonging to T-lymphocytes. T-lymphocytes are classified according to the secreted factors: 1) Th1 type T-lymphocytes, which produce IL-2, INF- $\gamma$ and TNF- $\alpha$ cytokines and determine the cell-mediated immune response; 2) and Th2 type T-lymphocytes, which produce IL-4, IL-5, IL-6, IL-10, IL-13 and promote humoral immune response. The pathogenetic line of Th17 CD 4+ T cells was described in 2005 (Rahman et al., 2005; Reich et al., 2005). T lymphocytes produce a broad spectrum of cytokines - IL-17A, IL-17F, IL-6, IL-21, and IL-22, TNF- $\alpha$, as shown in Figure 1. These cells play an important role in protection against infection and extracellular pathogens that cannot be effectively eliminated with Th1 and Th2 cell types, as well as in the development of autoimmune diseases and regulation of anti-tumour immune response (Jain et al., 2009; Martin et al., 2013; Qu et al., 2013; Chiricozzi et al., 2018).

Recent studies have shown the importance of $\mathrm{T}$ regulatory cells in the development of psoriasis. The primary function of these cells is to ensure immunological tolerance and to limit the immune response. In psoriasis, there is a lack of or dysfunction of $\mathrm{T}$ regulatory cells, which, in turn, elicits an inadequate immune response and is accompanied by a Th1 and Th17 mediated immune response (Hartmane et al., 2016; Gooderham et al., 2018). Currently, psoriasis is considered an autoimmune disease based on the activation of Th1 lymphocytes and hyperproduction of proinflammatory

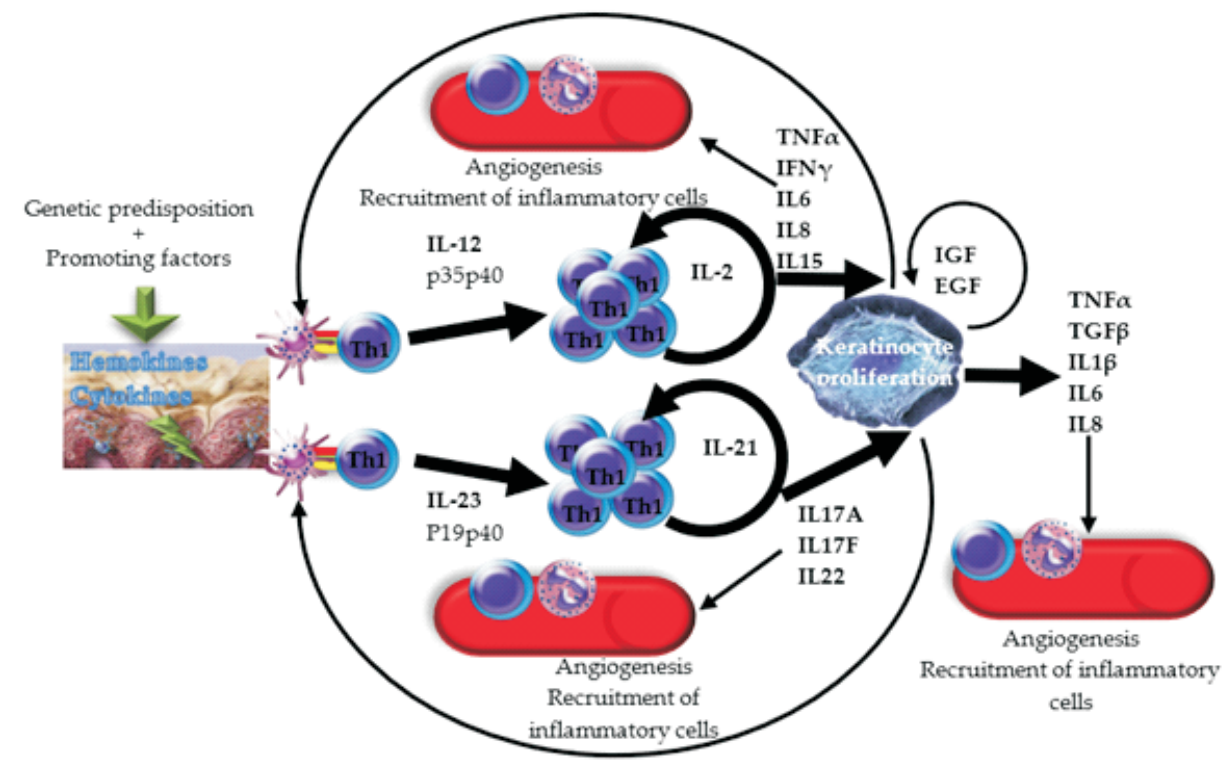

Fig. 1. Etiology of psoriasis (from Chiricozzi et al., 2018). 
cytokines TNF- $\alpha$, IFN- $\gamma$, IL-17 and IL-22, as well as due to the relative decrease in cytokine production by Th2 cells (Hartmane et al., 2016). Th17 lymphocytes also play a prominent role in psoriasis: their amount abundantly increases in psoriatic lesions and this increase is accompanied by the formation of characteristic morphological epidermal and dermal changes. In the skin, Th17 lymphocytes secrete proinflammatory cytokines TNF- $\alpha$, IL-17, IL-22, IL-23. They play a leading role in the pathogenesis of psoriasis and stimulate neutrophil leukocyte migration and angiogenesis, shown in Figure 1 (Mattozzi et al., 2013; Boehncke et al., 2014). An important role in the pathogenesis of psoriasis and psoriatic arthritis belongs to myeloid dendritic cells, which are produced in the psoriasis-affected dermis, and increased levels of IL-12 and IL-23. These cytokines promote the activation of $\mathrm{T}$ lymphocytes with subsequent differentiation in Th subpopulations 1 and 17 (Th1 and Th17) with their characteristic cytokines, including IL-17, which induce IL-6, IL-8, and other inflammatory proteins in keratinocytes (Wada et al., 2012; Mattozzi et al., 2013). In addition, IL-23 has been shown to enhance keratinocyte proliferation and interfere with differentiation, which in turn leads to epidermal acanthosis and characteristic psoriatic skin lesions. This cytokine is also important in the development of psoriatic arthritis (Gooderham et al., 2018).

Psoriasis is a polygenetic disease. The most frequently identified gene is PSORS1, with a specific locus on chromosome 6 (6p21). Various genetic variants associated with psoriasis have been reported with TNF- $\alpha$, IL-12/23 p40 and IL-23. Psoriasis is inherited as an autosomal dominant trait with incomplete penetration. Genetic factors are thought to cause psoriasis in $60-70 \%$ of cases. This is evidenced by the relatively high incidence of psoriasis among family members. Genetic markers of the risk of developing psoriasis are antigens of the human tissue compatibility antigen system (HLA). Based on these antigens, two types of psoriasis are distinguished. The first type (approximately $75 \%$ of patients) has a marked association with HLA antigens Cw6, A30, B13 or B57, and B-17, cases within family and its first manifestation in childhood. In such cases, the Koebner phenomenon (positive isomorphic reaction) can often be found. The second type of psoriasis is characterised by disease onset in adulthood, poor association with HLA and family history, with the Koebner phenomenon rarely being positive. Type 2 psoriasis is predominantly characterised by a moderate to severe disease course (Rahman et al., 2005; Griffiths et al., 2007).

The most important step in the pathogenesis of psoriasis is the imbalance of pro-inflammatory and inflammatory cytokines. An increased expression IL-1 $\beta$, IL-6, IL-10, IL-2, IL-8, IL-12, IL-15, IL-17, IL-22, IL-23, TNF- $\alpha$, IFN- $\gamma$ and IFN- $\alpha$ is found in psoriasis. TNF- $\alpha$ is one of the most important cytokines that induces immunopathological responses in psoriasis. It has many biological effects:

- Increases expression of cell and vascular adhesion molecule-1, which participates in lymphocyte migration to the area of inflammation.
- Activates lymphocytes and fibroblast proliferation.

- Stimulates the synthesis of leukotrienes, prostaglandins, and matrix metalloproteinase (especially collagenase), which induce cartilage and bone destruction.

By activating transcription factors, TNF- $\alpha$ regulates the activation of genes encoding cytokines IL-1, IFN- $\gamma$, GM-CSF, IL- 6 and proinflammatory chemokine IL-8. During the formation of inflammation, by acting on hepatocytes, TNF- $\alpha$ regulates the immune response by increasing $\mathrm{C}$-reactive protein. TNF- $\alpha$ initiates synthesis of free oxygen radicals and inhibits apoptosis of inflammatory cells. This cytokine takes an active role in bone remodelling by enhancing osteoclastogenesis and possibly promoting intraarticular osteolysis (a characteristic feature of psoriatic arthritis) (Rahman et al., 2006; Hartmane et al., 2016).

IL-17 also plays an important role in the development of immunological inflammation in psoriasis. This cytokine family includes IL-17A, B, C, D, E, F. Their primary function is the activation of synthesis of inflammatory cytokines. The physiological role of IL-17 is to protect the body from bacterial and fungal infections. In psoriasis, interaction of IL-17 with its receptors results in induction of the expression of pro-inflammatory cytokines, chemokines, adhesion molecules and growth factors, resulting in the progression of immune inflammation (Gaies et al., 2012). The function of IL-21 is to maintain Th17 cell balance. This cytokine increases the expression of IL-23 receptors (IL-23R) on T lymphocytes located in the inflammatory site, promoting the involvement of new Th17 cells in the pathological process.

Psoriatic lesions tend to recur in same areas previously affected by psoriasis, indicating the possible role of immune memory. This could be explained by the concept of Tissue Resident memory T cells. The best characterised TRM cells are CD8+ and express CD103 and CD69 (Watanabe et al., 2019). These cells are non-recirculating and persist long term in tissues, providing immediate protection against invading pathogens, and their inappropriate activation might contribute to the pathogenesis of autoimmune and inflammatory disorders. In the skin, apart from psoriasis, these cells have been described in vitiligo and melanoma (Malik et al., 2017; Boniface et al., 2018). Resolved psoriatic skin and disease-naïve non-lesional skin contain populations of IL-17-producing TRM cells with shared receptor sequences that recognise common antigens and likely contribute to disease recurrence after cessation of therapy (Matos et al., 2017). Looking at Il23/Il-17 axis targeting agents, the most rapid onset of action is observed with Il-17 inhibitors, whereas with Il-23 inhibitors onset of action is more gradual, but more sustainable over time, especially in a bio-experienced population (Reich et al., 2019). After biological treatment discontinuation, at the cellular and molecular levels, the residual disease activity or so called "scar" remains. In the future it seems that biological therapy selection will move from PASI 75, PASI 90, and PASI 100 to cellular and molecular level efficacy criteria, looking at 
"scar" resolution and healing on the molecular level, which halts the possibility for psoriasis recurrence (Benezeder et al., 2019). A similar approach is already adopted in some clinical trials for Crohn's disease and ulcerative colitis, looking beyond the endoscopic healing into histological mucosal healing and showing positive correlation with deep remission maintenance ( $\mathrm{Li}$ et al., 2019; Danese et al., 2020).

\section{PATHOGENETIC TREATMENT OPTIONS AVAIL- ABLE TO PSORIASIS PATIENTS IN BALTICS}

In psoriasis, IL-23 produced by Th17 lymphocytes interferes with terminal differentiation of keratinocytes, leading to changes in the epidermis. IL-23 levels correlate with disease severity (Hao et al., 2014; Gooderham et al., 2018). Published data indicate the importance of the immune system in the development of psoriasis, and therefore treatment choice should be based on pathogenetic mechanisms (Monteleone et al., 2011). Numerous publications are available on the use of immunosuppressive agents and methods (methotrexate, cyclosporine A, UVB phototherapy, PUVA, etc.) in the treatment of psoriasis. However, these agents do not provide high clinical efficacy (PASI 90), with unstable long-term efficacy and common serious side effects (Gaies et al., 2012). Biological therapeutic agents for the treatment of psoriasis are increasingly used in Europe and Baltic countries - treatments that target specific stages of disease pathogenesis and act by inhibiting specific pro-inflammatory cytokines or immunocompetent cells with specific inhibitors (Monteleone et al., 2011; From evolution to revolution...). In psoriasis, this type of treatment has several directions: inhibition of abnormal T-cell elimination, T-cell activation or migration block in tissues; immune correction to reverse the effects of cytokine activity (raising Th2 cytokine levels to normalise the Th1/Th2 imbalance), and binding of inflammatory cytokines (Mahil et al., 2016).

With the use of biological drugs in dermatological practice, there are two treatment stages: initiation and maintenance phases. The aim of the initiation phase is to determine the effectiveness and to evaluate possible advantages of continuing the therapy long-term. This phase lasts 12 to 28 weeks. The goal of maintenance therapy is to provide stable and long-term remission lasting from a few weeks to a few years (Mrowietz et al. 2014; Hartmane et al., 2016; Vide et al., 2017). Primary ineffectiveness due to the patient genetic characteristics can be overcome by optimising the dose or regimen (reducing the interval between injections), combining the biological with low doses of methotrexate or cyclosporine, and replacing one biological agent with another, preferentially switching the mechanism of action (Nast et al., 2012; Cather et al., 2014; Kerdel et al., 2015; Hartmane et al., 2016; Gisondi et al., 2017). Secondary ineffectiveness or loss of clinical efficacy is also possible, mainly due to the development of neutralising antibodies against the drug, which is highly relevant for TNF- $\alpha$ inhibitors, especially in the long-term use (Reich et al., 2005; Reich et al., 2012). The same methods are applied to correct secondary ineffectiveness as in the case of primary ineffectiveness (Mrowietz et al., 2014; Signorovitch et al., 2015; Hartmane et al., 2016). When combining a biological drug with methotrexate or cyclosporin $\mathrm{A}$, it is recommended to apply a stringent monitoring strategy, according to each particular drug's safety and toxicity profile. Safety monitoring intervals should be shorter in combination therapy. If toxicity is expected to increase, monitoring intervals may be shortened and additional monitoring parameters may be included (Mrowietz et al., 2014; Hartmane et al., 2016).

\section{SITUATION IN THE BALTICS}

Latvia, Lithuania, and Estonia operate in a restricted healthcare budget environment with certain similarities between countries in biologic reimbursement conditions and availability, as shown in Table 1. Starting from 2018, in all Baltic countries biologic medications are $100 \%$ reimbursed by the state.

Latvia. Biologicals in Latvia are indicated for the treatment of moderate to severe (severity index PASI $\geq 10$; damaged body surface area BSA $\geq 10 \%$ ) chronic psoriasis in patients for whom another systemic therapy with cyclosporin A, synthetic retinoids, methotrexate (conventional systemic therapy, CST) and phototherapy has been ineffective, contraindicated or poorly tolerated. In most cases, clinical efficacy of CST and phototherapy is evaluated at 3 to 6 months, and if no improvement is achieved in this time frame, the use of biological drugs is considered (Hartmane et al., 2016). According to data on reimbursed medicines for psoriasis diagnosis (ICD10 - L40.0-L40.5; L40.8) from the Latvian National Health Service in 2019, 11165 unique patients were treated, with more than 10000 patients treated with topical therapy (vitamin D analogues, steroids and extemporal preparations). With regards to psoriatic arthropathies (ICD 10 - M07.0-M07.3), 1060 unique patients were treated in 2019. These numbers are increasing compared to data from 2017. According to prescription conditions, biologic therapy could be prescribed in Latvia only in cases when patients have failed to achieve the treatment goal (loss of response) or have an adverse drug reaction for CST. In Latvia, $100 \%$ reimbursement for patients with psoriasis starting from January 2018 is in effect for three biologicals: adalimumab, ustekinumab, and secukinumab (Medicines to be reimbursed...; Use of public budget resources...). Currently in Latvia, 718 patients are being treated with conventional systemic therapy (MTX, CSP), and 113 receive biological therapy, with and increasing trend as indicated in Table 2 and supported by data for psoriatic arthritis (Tervishoiuteenuste loetelu....). Compared with the prevalence data, it seems that not all patients have access to treatment adequate for their disease severity, and a significant part of patients is not treated at all. Long-term use of topical steroids in a high proportion of population is indicative of patients not receiving treatment according to their disease severity. Treatment with biological medicines is prescribed or changed by a decision of a three-physician dermatovenerologist council at a tertiary 
Table 1. Comparison of biological therapy licensed for psoriasis in Europe and reimbursement status in Baltics

\begin{tabular}{|c|c|c|c|c|c|c|c|c|c|}
\hline Drug & $\begin{array}{l}\text { Mechanism of } \\
\text { action }\end{array}$ & $\begin{array}{c}\text { Dosage and } \\
\text { administration }\end{array}$ & $\begin{array}{l}\text { Number of } \\
\text { injections } \\
\text { in first year }\end{array}$ & $\begin{array}{c}\text { Efficacy } \\
\text { (PASI 75\% } \\
\text { at week } \\
10-16), \%\end{array}$ & $\begin{array}{c}\text { Efficacy } \\
\text { (PASI 90\% } \\
\text { at week } \\
10-16), \%\end{array}$ & $\begin{array}{l}\text { Long term } \\
\text { efficacy } \\
\text { PASI } 75 \% \\
\quad(24-52 \\
\text { week), \% } \\
\end{array}$ & $\begin{array}{l}\text { Long term } \\
\text { efficacy } \\
\text { PASI } 90 \% \\
(24-52 \\
\text { week), \% } \\
\end{array}$ & $\begin{array}{c}\text { Anti- } \\
\text { drug anti- } \\
\text { bodies, } \%\end{array}$ & $\begin{array}{l}\text { Reimbursement } \\
\text { status in Latvia, } \\
\text { Lithuania and } \\
\text { Estonia }\end{array}$ \\
\hline $\begin{array}{l}\text { Etanercept } \\
\text { (Enbrel } 25 \mathrm{mg} \\
\text { solution...) }\end{array}$ & $\begin{array}{l}\text { Dimeric human } \\
\text { fusion protein } \\
\text { mimicking } \\
\text { TNF- } \alpha \mathrm{R}\end{array}$ & $\begin{array}{l}50 \mathrm{mg} \text { twice } \\
\text { weekly } 3 \text { months } \\
\text { and then } 50 \mathrm{mg} \\
\text { weekly; SC }\end{array}$ & 80 & $47-49$ & 21 & $59-71$ & NR & $8.3-19.2$ & $\begin{array}{c}\text { LV - not available } \\
\text { LT - available } \\
\text { EE - available }\end{array}$ \\
\hline $\begin{array}{l}\text { Infliximab } \\
\text { (Remsima } 100 \\
\text { mg powder...) }\end{array}$ & $\begin{array}{l}\text { Chimeric IgG1 } \\
\text { monoclonal anti- } \\
\text { body that binds } \\
\text { to soluble and } \\
\text { transmembrane } \\
\text { forms of TNF- } \alpha\end{array}$ & $\begin{array}{l}5 \mathrm{mg} / \mathrm{kg} \text { every } 8 \\
\text { weeks following } \\
\text { doses at } 0,2 \text {, and } 6 \\
\text { weeks; IV }\end{array}$ & 7 & $75-88$ & 57.1 & 60.5 & 45.2 & 28 & $\begin{array}{c}\text { LV - not available } \\
\text { LT - available } \\
\text { EE - available }\end{array}$ \\
\hline $\begin{array}{l}\text { Adalimumab } \\
\text { (Humira } 40 \mathrm{mg} \\
\text { solution...) }\end{array}$ & $\begin{array}{l}\text { Human } \\
\text { monoclonal anti- } \\
\text { body against } \\
\text { TNF- } \alpha\end{array}$ & $\begin{array}{l}80 \mathrm{mg} \text { at week } 0 \text {, } \\
40 \mathrm{mg} \text { at week } 1 \\
\text { and then every } \\
\text { other week; SC }\end{array}$ & 26 & $53-80$ & $\begin{array}{c}\text { NR } \\
(\text { PASI100 }= \\
16.7-20)\end{array}$ & 74.7 & NR & 8.4 & $\begin{array}{l}\text { LV - available } \\
\text { LT - available } \\
\text { EE - available }\end{array}$ \\
\hline $\begin{array}{l}\text { Ustekinumab } \\
\text { (STELARA } 45 \\
\text { mg solution...) }\end{array}$ & $\begin{array}{l}\text { Human IgG1k } \\
\text { monoclonal anti- } \\
\text { body that binds } \\
\text { with specificity to } \\
\text { the p40 protein } \\
\text { subunit used by } \\
\text { both the } \\
\text { interleukin } \\
\text { (IL)-12 and IL-23 } \\
\text { cytokines } \\
\text { IL-12/IL-23 p40 }\end{array}$ & $\begin{array}{l}60 \mathrm{~kg}-0.75 \\
\mathrm{mg} / \mathrm{kg} \\
60 \mathrm{~kg}-100 \mathrm{~kg} \\
(220 \mathrm{lbs})-45 \mathrm{mg} \\
100 \mathrm{~kg}(220 \mathrm{lbs})- \\
90 \mathrm{mg} \text { Weeks } 0,4, \\
\text { and then every } 12 \\
\text { weeks thereafter; } \\
\mathrm{SC}\end{array}$ & 6 & $65-78$ & $66-76$ & $37-51$ & $54-56$ & $4-8.6$ & $\begin{array}{l}\text { LV - available } \\
\text { LT - available } \\
\text { EE - available }\end{array}$ \\
\hline $\begin{array}{l}\text { Secukinumab } \\
(\text { Cosentyx } 150 \\
\text { mg powder...) }\end{array}$ & $\begin{array}{l}\text { Human IgG1 } \\
\text { monoclonal anti- } \\
\text { body against } \\
\text { IL-17A }\end{array}$ & $\begin{array}{l}300 \mathrm{mg} \text { at weeks } 0 \text {, } \\
1,2,3 \text {, and } 4 \text { and } \\
\text { every } 4 \text { weeks } \\
\text { thereafter; SC }\end{array}$ & 35 & $\begin{array}{l}75.9- \\
86.1\end{array}$ & $\begin{array}{l}59.2- \\
69.8\end{array}$ & 74.3 & 60.0 & & $\begin{array}{c}\text { LV - available } \\
\text { LT - PRD } \\
\text { EE - available }\end{array}$ \\
\hline $\begin{array}{l}\text { Ixekizumab } \\
\text { (Taltz } 80 \text { mg so- } \\
\text { lution ... } \\
\text { Kyntheum } 210 \\
\text { mg solution...) }\end{array}$ & $\begin{array}{l}\text { Humanized, } \\
\text { immunoglobulin } \\
\text { G4 monoclonal } \\
\text { antibody selec- } \\
\text { tively binds and } \\
\text { neutralizes } \\
\text { IL-17A }\end{array}$ & $\begin{array}{l}160 \mathrm{mg} \text { at week } 0 \\
\text { and then } 80 \mathrm{mg} \text { ev- } \\
\text { ery } 2 \text { weeks until } \\
\text { week } 12 \text { and every } \\
4 \text { weeks thereafter; } \\
\text { SC }\end{array}$ & 18 & 88.2 & 72.8 & 88.2 & 76.5 & $9-17$ & $\begin{array}{c}\text { LV - PRD } \\
\text { LT - PRD } \\
\text { EE - available }\end{array}$ \\
\hline $\begin{array}{l}\text { Brodalumab } \\
\text { (Tremfya } 100 \\
\text { mg solution...) }\end{array}$ & $\begin{array}{l}\text { Human } \\
\text { monoclonal IgG2 } \\
\text { antibody directed } \\
\text { at the IL-17RA }\end{array}$ & $\begin{array}{l}210 \mathrm{mg} \text { at weeks } 0 \\
1, \text { and } 2 \text { and every } \\
2 \text { weeks thereafter; } \\
\text { SC }\end{array}$ & 28 & $83-86$ & $\begin{array}{l}\text { NR (PASI } \\
100-41.6)\end{array}$ & $65-87$ & $\begin{array}{c}\text { NR (PASI } \\
100-51.0)\end{array}$ & 2.7 & $\begin{array}{l}\text { LV - not available } \\
\text { LT - not available } \\
\text { EE - not available }\end{array}$ \\
\hline $\begin{array}{l}\text { Guselkumab } \\
\text { (Skyrizi } 75 \mathrm{mg} \\
\text { solution...) }\end{array}$ & $\begin{array}{l}\text { Human immuno- } \\
\text { globulin G1 } \\
\text { lambda (IgG1è) } \\
\text { monoclonal anti- } \\
\text { body that selec- } \\
\text { tively blocks IL-23 } \\
\text { by binding to its } \\
\text { p19 subunit }\end{array}$ & $\begin{array}{l}100 \mathrm{mg} \text { at weeks } 0 \\
\text { and } 4 \text { and every } 8 \\
\text { weeks thereafter; } \\
\text { SC }\end{array}$ & 8 & $\begin{array}{l}86.3- \\
91.2\end{array}$ & 73.3 & 87.8 & 76.1 & & $\begin{array}{c}\text { LV - PRD } \\
\text { LT - PRD } \\
\text { EE - available }\end{array}$ \\
\hline $\begin{array}{l}\text { Risankizumab } \\
\text { (Ilumetri } 100 \\
\text { mg solution...) }\end{array}$ & $\begin{array}{l}\text { Humanized IgG1 } \\
\text { monoclonal anti- } \\
\text { body that inhibits } \\
\text { interleukin- } 23 \text { by } \\
\text { specifically target- } \\
\text { ing the p19 subunit }\end{array}$ & $\begin{array}{l}150 \mathrm{mg} \text { at week } 0 \text {, } \\
\text { week } 4 \text {, and every } \\
12 \text { weeks thereaf- } \\
\text { ter; SC }\end{array}$ & 12 & 88 & 81 & 91.5 & $\begin{array}{l}80.6- \\
81.9\end{array}$ & 24 & $\begin{array}{c}\text { LV - PRD } \\
\text { LT - PRD } \\
\text { EE - available }\end{array}$ \\
\hline $\begin{array}{l}\text { Tildrakizumab } \\
\text { (Reimbursement } \\
\text { drug list...) }\end{array}$ & $\begin{array}{l}\text { Humanized IgG1, } \\
\text { which selectively } \\
\text { blocks IL-23 by } \\
\text { binding to its p19 } \\
\text { subunit }\end{array}$ & $\begin{array}{l}100 \mathrm{mg} \text { at weeks } 0 \text {, } \\
\text { and } 4 \text { and every } 12 \\
\text { weeks thereafter; } \\
\text { SC }\end{array}$ & 6 & $\begin{array}{l}61- \\
63.8\end{array}$ & $\begin{array}{c}34.6- \\
38.8\end{array}$ & $\begin{array}{l}73.5- \\
80.4\end{array}$ & $\begin{array}{l}55.5- \\
78.4\end{array}$ & 7.4 & $\begin{array}{l}\text { LV - not available } \\
\text { LT - not available } \\
\text { EE - not available }\end{array}$ \\
\hline
\end{tabular}

NR, not reported, SC, sub cutaneous, IV, intravenous, LV, Latvia, LT, Lithuania, EE, Estonia, CSP, cyclosporin, MTX, methotrexate, PRD, pending reimbursement decision 
Table 2. Dynamics of treated patients in Latvia for the period from 2017 to 2019 for diagnosis psoriasis and psoriatic arthritis

\begin{tabular}{c|c|c|c}
\hline Year & $\begin{array}{c}\text { Unique patients treated with } \\
\text { reimbursed medicines for diagnosis } \\
\text { Psoriasis (ICD 10 - L40.0-L40.5; } \\
\text { L40.8) }\end{array}$ & $\begin{array}{c}\text { Unique patients treated with } \\
\text { reimbursed medicines for diagnosis } \\
\text { Psoriatic arthritis } \\
\text { (ICD 10 - M07.0-M07.3) }\end{array}$ & Comment \\
\hline 2017 & 10016 & 882 & $\begin{array}{l}\text { For PsA medicines were reimbursed by 50 or 100\%. For PsO } \\
\text { medicines were reimbursed 50\%, 75\% or 100\%. }\end{array}$ \\
2018 & 10609 & $\begin{array}{l}\text { For PsO medicines were reimbursed for 75\% or 100\%, inclusion of } \\
\text { first biological therapy into reimbursement list. PsA reimbursed 100\% }\end{array}$ \\
2019 & 11165 & For both PsO and PsA 100\% reimbursement
\end{tabular}

$\mathrm{PsO}$, psoriasis, PsA, psoriatic arthritis (Use of public budget resources...)

level outpatient and/or inpatient dermatovenerology service provider. Treatment could be continued by a dermatovenerologist at the secondary outpatient dermatovenerology service provider. Treatment is followed up according to local guidelines (Hartmane et al., 2016). Currently, reimbursed systemic therapy in Latvia does not fully correspond to European professional association guidelines with requirement to always start with the cheapest biologic therapy, which in the current situation in anti-TNFs (Nast et al., 2012). This puts dermatologists in a certain dilemma how to achieve the best results with the government-imposed therapy sequence. Second line biologic therapy available is secukinumb and ustekinumab, based on dermatovenerologist council decision. A similar problem is observed in other Baltic countries.

Estonia. A dermatovenerologist and pediatrician expert council can initiate first line biologic therapy for a patient meeting the following conditions: the disease has lasted for at least six months and previous treatments have been ineffective or intolerable and at least one of the following occurs: alternative standard systemic therapy (acitretin, cyclosporine, methotrexate, bundle UVB and Psoralen + UVA photochemotherapy) is contraindicated; there is a form of psoriasis that requires recurrent hospitalisations; there is an unstable, life-threatening psoriasis form (erythrodermic or pustular psoriasis) with a PASI score or BSA score $>=10$ and DLQI $>=10$. In Estonia, $1^{\text {st }}$ line biologic therapy is anti-TNF (adalimumab or etanercept, available as prescription medicines). If there is lack of effect or intolerance to $1^{\text {st }}$ line biologic therapy, it is possible to proceed to $2^{\text {nd }}$ line therapy: infliximab, which is covered by hospital service fee. If there is lack of effect or intolerance to $2^{\text {nd }}$ line biologic therapy, then it is possible to proceed to 3rd line biologic therapy - ustekinumab, secukinumab, guselkumab, ixekizumab or risankizumab. Treatment with the biological disease modifying drug is discontinued or replaced by another biological if the patient does not show a $75 \%$ improvement in the PASI score by week 14 of treatment, compared to pre-treatment, or a $50 \%$ improvement in PASI score or BSA score and a $5 \%$ reduction in DLQI points compared to pre-treatment. Treatment with a biological medicine should be discontinued in a patient with psoriasis ineffectiveness if the use of the three active substances has not achieved the results (Order for the approval ...). This fact highlights new challenges in treating patients who have failed three biologics, and careful treatment sequence selection. More data are needed to help in identifying the optimal treatment sequence for different patient subgroups. In Estonia, 5963 patients are receiving systemic therapy for psoriasis, from which 214 are receiving biological therapy (Order for the approval ...).

Lithuania. Treatment with biological medicines is indicated for the treatment of severe psoriasis (PASI > 15) persistent for more than six months, when phototherapy or standard systemic therapy (MTX or acitretin) has been ineffective or contraindicated. Treatment with biological medicines is prescribed, changed, or discontinued (except for continuity) in the event of remission by a decision of a three-physician dermatovenerologist council at a tertiary level outpatient and/or inpatient dermatovenerology service provider. Treatment with biological medicines is continued by a dermatovenerologist at the tertiary level outpatient and/or inpatient dermatovenerology services. The order of prescribing biological therapy is determined on the basis of the minimum annual cost of treatment. The $1^{\text {st }}$ line biologic agent is anti-TNF $\alpha$. Medications other than the $1^{\text {st }}$ line anti-TNF $\alpha$ can be given in certain cases: 1) if the patient does not tolerate MTX or cannot be co-administered with infliximab, etanercept, adalimumab, ustekinumab; 2) if the patient is after tuberculosis treatment, has latent tuberculosis or inactive viral hepatitis, etanercept is given, and if etanercept is intolerable or ineffective, ustekinumab is given; 3) if the patient has non-infectious IBD or uveitis, infliximab or adalimumab should be selected; 4) if the patient has purulent hydradenitis, adalimumab can be given; 5 ) if the patient is allergic to one of the anti-TNF $\alpha$, another anti-TNF $\alpha$ or biologic with a different mechanism of action should be used. The patient is examined by a dermatovenerologist every 1-3 months. The purpose of the patient's treatment is remission of the disease or low disease activity. This goal should be achieved within six months, but if no improvement is seen after three months, treatment should be adjusted. The treatment effect is evaluated according to the dynamics of the following indicators: if the PASI rate improved by $\geq 75 \%$, treatment is continued; if the PASI rate has improved $<50 \%$, treatment is changed; if the PASI rate has improved by $50-74 \%$ and the DLQI is $\leq 5$, treatment is continued and; if DLQI $>5$, then the treatment is changed 
(Ministry of Health of the Republic of Lithuania...). In Lithuania about 1100 patients are receiving systemic therapy and 330 receive biological therapy, and significant patient pool of about 20000 uses topical therapy (vitamin D analogues, topical corticosteroids, as well as extemporal preparations), indicating overuse of topical steroids in presumably moderate-to-severe psoriasis (Ministry of Health of the Republic of Lithuania...).

\section{PERSPECTIVES FOR FUTURE}

The Baltic countries lack data on precise prevalence and incidence numbers of psoriasis patients. None of the counties has government-owned registries comprehensive for psoriasis and in Estonia the registry is for biologic therapy patients. Latvia and Lithuania have a potentially high number of psoriasis patients not receiving any treatment according to prevalence data and number of treated patients, and also relatively low numbers of patients receiving systemic therapies, compared to Estonia. More research is needed to understand the reasons behind this phenomenon. The low number of patients receiving biological therapy might be explained by reluctancy in use of systemic therapies.

Additional challenges in clinical practice are set by reimbursement conditions that are changing every three months. Currently, anti-TNFs are the first line biologic therapy in all Baltic countries, which require caution in direct implementation of data from trials into Baltic clinical practice, as in the majority of cases before initiation of interleukin inhibitors (either Il12/23, Il-17 or Il-23), patients will be anti-TNF-experienced. The authors therefore suggest proceeding with a quick switch of therapy if satisfactory treatment results are not achieved within 12-16 therapy weeks on anti-TNFs and strongly suggest against anti-TNF recycling. Safety switches should be conducted as soon as possible (Menter et al., 2011; Hartmane et al., 2016). This approach allows more flexible modification of the therapy and treatment optimisation for primary non-responders to anti-TNFs. When choosing second line biologics in the restricted reimbursement environment, several important aspects must be considered: efficacy of a biologic drug in a bio-experienced population, long-term maintenance of response, long-term safety data, ease and frequency of administration, and the immunogenicity profile. Longer drug survival becomes of utmost importance in limited biologic therapy availability regions, and additionally protects patients from exposure to medication with different immunogenicity profiles (Nast et al., 2012; Hartmane et al., 2016).

Limitations of this review concern patient number estimations, since these numbers were derived from national authority reported drug consumption data for diagnosis of psoriasis, and this may not accurately reflect the patient split according to disease severity. Additional studies and registries are needed for psoriasis in Baltics to address this data gap.

\section{CONCLUSIONS}

To our knowledge this is the first article providing a review of psoriasis forms and pathogenesis with a comprehensive overview of the reimbursement situation in Baltic countries for biological therapies and providing previously unpublished data on numbers of treated patients.

\section{CONFLICT OF INTEREST STATEMENT}

Ilona Hartmane received consulting fees and a speaker honoraria from Novartis, AbbVie and Janssen, investigator honoraria from Novartis and Amgen.

Ingmars Mikažāns received consulting fees and a speaker honoraria from Novartis, AbbVie and Janssen; investigator honoraria from Pfizer and Amgen.

Iveta Ivdra received a speaker honoraria from Novartis and Sandoz.

Vanda Bondare-Ansberga received financial support in medical education event attendance and a speaker honoraria from Janssen. Consulting fee for consulting MSD and Phorphase Ltd./Celonova Biosciences.

\section{ACKNOWLEDGMENTS}

We would like to thank Irena Mirzajanova Msc.Clin.Pharm (Janssen) for intellectual assistance and technical support.

\section{REFERENCES}

Benezeder, T., Wolf, P. (2019). Resolution of plaque-type psoriasis: What is left behind (and reinitiates the disease). Springer Semin. Immunopathol, 32 (6), 1-12.

Boehncke, W. H., Boehncke, S. (2014). More than skin-deep: The many dimensions of the psoriatic disease. Swiss Med. Wkly., 144 (171), 68-75.

Boniface, K., Jacquemin, C., Darrigade, A. S., Dessarthe, B., Martins C., Boukhedouni, N. (2018). Vitiligo skin is imprinted with resident memory CD8 T cells expressing CXCR3. J. Invest. Dermatol., 138 (2), 355-364.

Cather, J. C., Crowley, J. J. (2014). Use of biologic agents in combination with other therapies for the treatment of psoriasis. Amer. J. Clin. Dermatol., 15 (6), 467-478.

Chiricozzi, A., Romanelli, .P., Volpe, E., Borsellino, G., Romanelli, M. (2018). Scanning the immunopathogenesis of psoriasis. Int. J. Mol. Sci., 19 (1), 179-185

Christophers, E. (2001) Psoriasis - epidemiology and clinical spectrum. Clin. Exp. Dermatol., 26 (4), 314-320.

Christophers, E., van de Kerkhof, P. C. (2019). Severity, heterogeneity and systemic inflammation in psoriasis. J. Eur. Acad. Dermatol. Venereol., 33 (4), 643-647.

Cosentyx $150 \mathrm{mg}$ powder for solution for injection. SmPC. https://www.ema.europa.eu/en/documents/product-information/ cosentyx-epar-product-information_en.pdf (accessed 15 March 2020).

Danese, S., Vermeire, S., D’Haens, G., Panés J., Dignass, A., Magro F. (2020). DOP13 Clinical and endoscopic response to ustekinumab in Crohn's disease: Week 16 interim analysis of the STARDUST trial. $J$. Crohns Colitis, 14 (1), 49-52. 
Dubertret, L., Mrowietz, U., Rank., A, Van De Kerkhof, P. C., Chimenti, S., Lotti, T. (2006) . EUROPSO patient survey. European patient perspectives on the impact of psoriasis: The EUROPSO patient membership survey. Brit. J. Dermatol., 155 (4), 729-736.

Eder, L., Haddad, A., Rosen C. F., Lee K. A., Chandran V., Cook, R. (2016). The incidence and risk factors for psoriatic arthritis in patients with psoriasis: A prospective cohort study. Arthritis Rheum., 68 (4), 915-923.

Enbrel $25 \mathrm{mg}$ solution for injection in pre-filled syringe Enbrel $50 \mathrm{mg}$ solution for injection in pre-filled syringe. SmPC.

https://www.ema.europa.eu/en/documents/product-information/ enbrel-epar-product-information_en.pdf on 10/03/2020 (accessed 01.03.2020)

From evolution to revolution: IL-23 in the treatment of psoriasis patients. EMJ Dermatol., 6, 71-78. https://www.emjreviews.com/dermatology/ symposium/from-evolution-to-revolution-il-23-in-the-treatment-of-psoriasis-patients (accessed 01.03.2020)

Gaies, E., Jebabli, N., Trabelsi, S., Salouage, I., Charfi, R., Lakhal, M. (2012). Methotrexate side effects: Review article. J. Drug Metab. Toxicol., 3 (4), 1-5.

Gisondi, P., Del Giglio, M., Girolomoni, G. (2017). Treatment approaches to moderate to severe psoriasis. Int. J. Mol., 18 (11), 2427-2429.

Global Psoriasis Atlas. https://globalpsoriasisatlas.org/statistics (accessed 20.04.2020)

Gooderham, M. J., Papp, K. A., Lynd, C.W. (2018). Shifting the focus-the primary role of IL-23 in psoriasis and other inflammatory disorders. J. Eur. Acad. Dermatol. Venereol., 32 (7), 1111-1119.

Griffiths, C. E., Barker, J. N. (2007). Pathogenesis and clinical features of psoriasis. The Lancet, 370, 263-271.

Hao, J. Q. (2014). Targeting interleukin-22 in psoriasis. Inflammation, 37 (1), 94-99.

Hartmane, I., Mikažāns, I., Ivdra, .I, Dērveniece, A., Ančupāne, I. (2016). Experience of phototherapy in dermatological praxis in complex therapy of psoriasis patients. Proc. Latv. Acad. Sci. Section B, 70 (1), 7-12.

Humira $40 \mathrm{mg}$ solution for injection in pre-filled syringe Humira $40 \mathrm{mg}$ solution for injection in pre-filled pen. SmPC. Last revised 08/09/2008. https://www.ema.europa.eu/en/documents/product-information/ humira-epar-product-information_en.pdf (accessed 15.03.2020).

Ilumetri $100 \mathrm{mg}$ solution for injection in pre-filled syringe. SmPC. Last revised 17/09/2018. https://www.ema.europa.eu/en/documents/productinformation/ilumetri-epar-product-information_en.pdf on 10/03/2020 (accessed 15.03.2020)

Jain, S., Kaur, I. R., Das, S., Bhattacharya, S. N. Singh, A. (2009) T helper 1 to $\mathrm{T}$ helper 2 shift in cytokine expression: An autoregulatory process in superantigen-associated psoriasis progression? J. Med. Microbiol., 58 (2), $180-184$.

Kerdel, F., Zaiac, M. (2015). An evolution in switching therapy for psoriasis patients who fail to meet treatment goals. Dermatol. Ther., 28 (6), 390-403.

Kyntheum $210 \mathrm{mg}$ solution for injection in pre-filled syringe. SmPC. Last revised 17/07/2017. https://www.ema.europa.eu/en/documents/productinformation/kyntheum-epar-product-information_en.pdf (accessed 15.03. 2020).

Li, K., Joshua, F. R., Marano, C., Zhang, H., Yang, F., Feagan, B. G. (2019). Effects of ustekinumab induction therapy on endoscopic and histologic healing in the UNIFI phase 3 study in Ulcerative Colitis. Z. Gastroenterol., 57 (5), 169-187.

Mahil, S. K., Capon, F., Barker J. N. (2016). Update on psoriasis immunopathogenesis and targeted immunotherapy. Springer Semin. Immunopathol., 38 (1), 11-27.
Malik, B. T., Byrne, K. T., Vella, J. L., Zhang, P., Shabaneh, T. B., Steinberg, S. M. (2017). Resident memory T cells in skin mediate durable immunity to melanoma. Sci. Immunol., 2 (10), 35-47.

Marti, D. A.,Towne, J. E., Kricorian, G., Klekotka, P., Gudjonsson, J. E., Krueger, J. G. (2013). The emerging role of IL-17 in the pathogenesis of psoriasis: Preclinical and clinical findings. J. Invest Dermatol., 133 (1), $17-26$

Matos, T. R., O’Malley, J. T., Lowry, E. L., Hamm, D., Kirsch I. R. (2017) Clinically resolved psoriatic lesions contain psoriasis-specific IL-17-producing $\alpha \bar{a}$ T cell clones. J. Clin. Invest., 127 (11), 4031-4041.

Mattozzi, C., Salvi M., D'epiro, S., Giancristoforo, S., Macaluso, L., Luci, C. (2013). Importance of regulatory T cells in the pathogenesis of psoriasis. Dermatology, 227 (2), 134-145.

Medicines to be reimbursed. Nacionālais Veselības Dienests [National Health Service].

http://www.vmnvd.gov.lv/en/cross-border-healthcare-contact-point/ health-care-in-latvia/medicines-to-be-reimbursed on 06/04/2020 (accessed 15.04. 2020).

Menter, A., Korman, N. J., Elmets, C. A., Feldman, S. R., Gelfand, J. M., Gordon, K. B. (2011). Guidelines of care for the management of psoriasis and psoriatic arthritis. Section 6. Guidelines of care for the treatment of psoriasis and psoriatic arthritis: Case-based presentations and evidence-based conclusions. J. Amer. Acad. Dermatol., 65 (1), 137-174.

Ministry of Health of the Republic of Lithuania. http://sam.lrv.lt/en/ (accessed 15.04.2020).

Möller, A. H, Erntoft, S., Vinding, G. R., Jemec G. B. (2015). A systematic literature review to compare quality of life in psoriasis with other chronic diseases using EQ-5D-derived utility values. Patient Relat. Outcome Meas., 6, 167-177.

Monteleone, G., Pallone F., MacDonald, T. T., Chimenti, S., Costanz, A (2011). Psoriasis: From pathogenesis to novel therapeutic approaches. Clin. Sci., 120 (1), 8-12.

Mrowietz, U., De Jong, E. M., Kragballe, K., Langley, R., Nast, A., Puig, L. (2014). A consensus report on appropriate treatment optimization and transitioning in the management of moderate-to-severe plaque psoriasis. $J$. Eur. Acad. Dermatol. Venereol., 28 (4), 438-453.

Mrowietz, U., Kragballe, K., Reich, K., Spul, P., Griffiths. C. E., Nast, A (2011). Definition of treatment goals for moderate to severe psoriasis:A European consensus. Arch. Dermatol. Res., 303 (1), 1-10.

Nast, A., Boehncke, W. H., Mrowietz, U., Ockenfels, H. M., Philipp, S., Reich, K. (2012). S3-Guidelines on the treatment of psoriasis vulgaris (English version). Update. J. Dtsch. Dermatol. Ges., 10, 1-95.

Order for the approval of the procedure for the treatment of psoriasis with medicinal products the purchase of which is covered by the compulsory health insurance fund's budget. Ministry of Health of Republic of Lithuania. https://www.e-tar.1t/portal/en/legalAct/ c51f3b408d8311e7a3c4a5eb10f04386/nHZdKhSspS on 06/04/2020 (accessed 15.04.2020) (in Lithuanian).

Owczarczyk-Saczonek, A., Czerwińska, J., Placek, W. (2018). The role of regulatory $\mathrm{T}$ cells and anti-inflammatory cytokines in psoriasis. Acto Dermatovenerol. Alp. Pannonica Adriat., 27 (1), 17-23.

Parisi, R., Symmons, D. P, Griffiths, C. E, Ashcrof, D. M.(2013). Global epidemiology of psoriasis: A systematic review of incidence and prevalence. J. Investig. Dermatol.., 133 (2), 377-385.

Qu, N., Xu, M., Mizoguchi, I., Furusawa, J. I., Kaneko, K., Watanabe, K. (2013). Pivotal roles of T-helper 17-related cytokines, IL-17, IL-22, and IL-23, in inflammatory diseases. Clin. Dev. Immunol., 34 (16), 231-235.

Rahman, P., Elder, J. T. (2005). Genetic epidemiology of psoriasis and psoriatic arthritis. Ann. Rheum. Dis., 64 (2), 37-49. 
Rahman, P., Siannis, F., Butt, C., Farewell, V., Peddle, L., Pellett, F (2006). TNF $\alpha$ polymorphisms and risk of psoriatic arthritis. Ann. Rheum. Dis., 65 (7), 919-923.

Reich, K., Armstrong, A. W., Langley, R. G., Flavin, S., Randazzo, B., Li, S (2019). Guselkumab versus secukinumab for the treatment of moderate-to-severe psoriasis (ECLIPSE): Results from a phase 3, randomised controlled trial. The Lancet, 394 (1 0201), 831-839.

Reich, K. (2012). The concept of psoriasis as a systemic inflammation: Implications for disease management. J. Eur. Acad. Dermatol. Venereol., 26, 3-11.

Reich, K., Burden, A. D., Eaton, J. N., Hawkins, N. S. (2012). Efficacy of biologics in the treatment of moderate to severe psoriasis: A network meta-analysis of randomized controlled trials. Brit. J. Dermatol., 166 (1), $179-188$.

Reich, K., Nestle, F. O., Papp, K., Ortonne, J. P., Evans, R, Guzzo, C., Li, S., Dooley, L. T., Griffiths, C. E., (2005). EXPRESS Study Investigators. Infliximab induction and maintenance therapy for moderate-to-severe psoriasis: A phase III, multicentre, double-blind trial. The Lancet, 366 (9494), 1367-1374.

Reimbursemen drug list. Nacionālais Veselības Dienests [National Health Service].

http://www.vmnvd.gov.lv/lv/kompensejamie-medikamenti/kompensejam o-zalu-saraksts from 06/04/2020 (accessed 15.04. 2020).

Remsima $100 \mathrm{mg}$ powder for concentrate for solution for infusion. SmPC. Last revised 21/06/2018. https://www.ema.europa.eu/en/documents/ product-information/remsima-epar-product-information_en.pdf (accessed 15.04. 2020)

Rendon, A, Schäkel, K. (2019). Psoriasis pathogenesis and treatment. Int. J. Mol. Sci., 20 (6), 1475.

Signorovitch, J. E., Betts, K.A., Yan, Y. S., LeReun, C., Sundaram, M., Wu, E. Q., Mulani, P. (2015). Comparative efficacy of biological treatments for moderate-to-severe psoriasis: A network meta-analysis adjusting for cross-trial differences in reference arm response. Brit. J. Dermatol., 172 (2), 504-512.

Skyrizi $75 \mathrm{mg}$ solution for injection in pre-filled syringe. SmPC. Last revised 26/04/2019. https://www.ema.europa.eu/en/documents/product-information/skyrizi-epar-product-information_en.pdf (accessed 15.04.2020).
STELARA $45 \mathrm{mg}$ solution for injection STELARA $90 \mathrm{mg}$ solution for injection STELARA $45 \mathrm{mg}$ solution for injection in pre-filled syringe STELARA $90 \mathrm{mg}$ solution for injection in pre-filled syringe. SmPC. Last revised 19/09/2013. https://www.ema.europa.eu/en/documents/productinformation/stelara-epar-product-information_en.pdf (accessed 15.04.2020).

Takeshita, J., Grewal, S., Langan, S. M., Mehta, N. N., Ogdie A., Van Voorhees A. S. (2017). Psoriasis and comorbid diseases: Epidemiology. $J$. Amer. Acad. Dermatol. 76 (3), 377-390.

Taltz $80 \mathrm{mg}$ solution for injection in pre-filled syringe. SmPC. Last revised 25/04/2016. https://www.ema.europa.eu/en/documents/product-information/ taltz-epar-product-information_en.pdf (accessed 15.04. 2020).

Tervishoiuteenuste loetelu.

https://www.haigekassa.ee/partnerile/raviasutusele/tervishoiuteenuste-loe telu on 06/04/2020 (accessed 15.04.2020).

Tremfya $100 \mathrm{mg}$ solution for injection in pre-filled syringe. Tremfya $100 \mathrm{mg}$ solution for injection in pre-filled pen. SmPC. Last revised 10/11/2017. https://www.ema.europa.eu/en/documents/product-information/ tremfya-epar-product-information_en.pdf (accessed 15.04. 2020).

Use of public budget resources to pay national reimburses [Valsts budžeta līdzekḷu izlietojums valsts kompensējamo zāḷu apmaksā]. Nacionālais Veselības Dienests [National Health Service].

http://vmnvd.gov.lv/lv/ligumpartneriem/operativa-budzeta-informacija/v alsts-budzeta-lidzeklu-izlietojums-valsts-kompensejamo-zalu-apmaksa on 07/04/2020 (accessed 15.04.2020).

Vide, J., Magina S, (2017). Moderate to severe psoriasis treatment challenges through the era of biological drugs. An. Bras. Dermatol., 92 (5), 668-674.

Wada, Y., Cardinale, I., Khatcherian, A., Chu, J., Kantor, A. B., Gottlieb, A.B. (2012). Apilimod inhibits the production of IL-12 and IL-23 and reduces dendritic cell infiltration in psoriasis. PloS One, 7 (4), 1371-1380.

Watanabe, R. (2019). Protective and pathogenic roles of resident memory T cells in human skin disorders. J. Dermatol. Sci., 31 (5), 151-157.

Yeung, H., Takeshita, J., Mehta, N. N., Kimmel, S. E., Ogdie, A., Margolis, D. J., Shin, D. B., Attor, R., Troxel, A. B., Gelfand, J. M. (2013). Psoriasis severity and the prevalence of major medical comorbidity: A population-based study. JAMA Dermatol., 149 (10), 1173-1179.

Received 11 June 2020

Accepted in the final form 1 March 2021

\section{IMUNOPATOGĒNISKAS ĀRSTĒŠANAS IESPĒJAS PSORIĀZES PACIENTIEM IEROBEŽOTAS MADIKAMENTU IEGĀDES KOMPENSĀCIJAS VIDĒ}

Šĩ raksta mērḳis ir sniegt pārskatu par psoriāzi, pieejamajām ārstēšanas iespējām vidēji smagas līdz smagas psoriāzes gadījumos. Sniegti autoru ieteikumi par dažādu bioloğisko līdzekḷu lietošanu pacientiem ar psoriāzi Baltijā vidē, kur ir ierobežoti medikamentu iegādes kompensācijas mehānismi. 